\title{
CODE-SWITCHING USED BY SACHA STEVENSON IN TALK SHOWS
}

\author{
(Alih Kode yang Digunakan oleh Sacha Stevenson dalam Talk Show)
}

\author{
Ahmad Faiz \\ Magister Linguistik, University of Brawijaya Malang \\ Jalan Veteran, Malang, Jawa Timur 65145, Indonesia \\ Pos-el: Faizelf13@gmail.com
}

\begin{abstract}
This research investigates the use of types and functions of code-switching used by Sacha Stevenson as a guest star in Tonight Show and Sarah Sechan on NET TV. Tonight Show and Sarah Sechan are two popular talk shows on NET TV. In order to find the type and the function of codeswitching used, the writer uses descriptive qualitative approach. The data is in the form of conversation. In order to collect the data, the writer compiles videos based on the sequence and the context of the conversation. The result shows that the types of code-switching found in both sources are intra-sentential code-switching, inter-sentential code-switching and establishing continuity toward previous speaker emblematic or tag-switching. The functions of code-switching found in both data sources are covering the difficulty in speaking Indonesian, reducing or avoiding face and increasing prestige to be viewed as an educated person and covering inability in speaking Indonesian. This research cannot do a direct interview with Sacha Stevenson. Therefore, it can give chance to other researchers to find the reason of using code-switching used by Sacha Stevenson which can be applied by observing and interviewing her immediately.
\end{abstract}

Keywords: code-switching, Sacha Stevenson, Tonight Show, Sarah Sechan,

\begin{abstract}
Abstrak: Penelitian ini menganalisis penggunaan jenis dan fungsi alih kode yang digunakan oleh Sacha Stevenson sebagai bintang tamu di Tonight Show dan Sarah Sechan di NET TV. Tonight Show dan Sarah Sechan adalah dua gelar wicara populer di NET TV. Untuk mengetahui jenis dan fungsi pengalihan kode yang digunakan oleh Sacha Stevenson di Tonight Show dan Sarah Sechan di NET TV, penulis menggunakan pendekatan deskriptif kualitatif. Data berupa percakapan. Pengambilan data dilakukan dengan mengumpulkan data dari video berdasarkan urutan dan konteks percakapan. Hasilnya menunjukkan bahwa jenis kode-switching yang ditemukan di kedua sumber adalah kode intra-sentential code-switching, inter-sentential code-switching dan membangun kontinuitas terhadap penyisipan atau pengalihan tag (kata atau frasa) pembicara sebelumnya. Fungsi pengalihan kode yang ditemukan di kedua sumber data ini mencakup kesulitan dalam berbicara bahasa Indonesia, mengurangi atau memalingkan wajah dan meningkatkan prestise agar dipandang sebagai orang yang berpendidikan dan tidak mampu berbicara dalam bahasa Indonesia. Dalam penelitian ini penulis tidak melakukan wawancara langsung dengan Sacha Stevenson. Hal ini dapat memberi kesempatan kepada peneliti lain untuk menemukan alasan penggunaan kode alih yang digunakan oleh Sacha Stevenson yang bisa diaplikasikan dengan mengamati dan secara langsung mewawancarainya.
\end{abstract}

Kata Kunci: alih kode, Sacha Stevenson, Tonight Show dan Sarah Sechan on NET TV

\section{INTRODUCTION}

This research investigates code-switching used by Sacha Stevenson on two talk shows in Indonesian TV programs uploaded in YouTube; those are Tonight Show on Net TV and Sarah Sechan on NET TV. The main purpose of this research is to identify the types and functions of code-switching on Sacha Stevenson's speech which is uttered on those talk shows. Romaine (1996) argued that code-switching is an important topic in the field of 
sociolinguistics. It is a phenomenon in daily conversation.

Sacha Stevenson is a famous person in Indonesia. She is from Canada. She has been living in Indonesia for 11 years. Her videos uploaded in YouTube have attracted many people and viewed by more than a thousand viewers. This research analysed her code-switching in the two talk shows, namely Tonight Show and Sarah Sechan. Both talk shows have the biggest viewers in YouTube interviewing Sacha Stevenson. The audiences of the two talk shows are Indonesian so she spoke Indonesian. In certain conversation, she used English which caused code-switching occurred.

Code-switching has been investigated by several researchers. Ibrahim, Shah, \& Armia (2013) analysed teacher's attitudes toward English as foreign language in International Islamic University of Malaysia. This research investigated the teacher's attitude toward code-switching and the functions of code-switching in the classroom. The researcher uses Gumperz theory.

Kumalasari (2008) analysed codeswitching conversations in Empat Mata talk show in Trans 7. It looks for the type and the reasons of code-switching used. That research focuses on the type and the function of using code-switching based on Holmes theory. This research also focuses on the same issues applying the same theory.

Those all previous studies analysed code-switching produced by Indonesian people. However, this research analyzes code-switching used by a native English speaker that is Sacha Stevenson. She is even also able to speak Indonesian fluently. The potential findings of this research are that Sacha Stevenson would like to do code-switching as covering inability in speaking Indonesian. The research problems are what type and function of code-switching used by Sasha Stevenson in Tonight Show and Sarah Sechan. The objectives are to find type and function of code-switching used by Sacha Stevenson in Tonight Show and Sarah Sechan. Therefore, this research analyzes her codeswitching in two talk shows; those are Tonight Show and Sarah Sechan.

The writer limits the research by focusing in the object of the study that is Sacha Stevenson's speech, a native English speaker who can speak Indonesian fluently. It is very important because there are many people misunderstand why people using certain code-switching. Some may think the use of code-switching is such an arrogant person. The result of this research can make some people know more about the type and the function of code-switching and even if the user of code-switching is an English native speaker who can speak English fluently. Therefore, they will not misjudge and misunderstand people using codeswitching in an Indonesian-conversation language.

\section{METHOD}

This research uses a descriptive qualitative research approach. Descriptive is a method in which the analysis process is in the form of words. Thus, this research describes the type and the functions of code-switching used by Sacha Stevenson. Creswell (1994) stated that qualitative research is a research methodology which is its process, meaning, and understanding are known through words and pictures. It attempts to have a deep understanding in the context of the data.

The data sources in this research were taken from Tonight Show which is broadcasted on 14th June, 2014 and Sarah Sechan on 30th September, 2013, on NET TV. The talk shows chosen are those interviewing Sacha Stevenson. The videos of the talk shows were downloaded from YouTube. This study uses human instrument because the writer himself is the instrument to collect the data.

Steps in collecting the data were as follows. Firstly, the writer downloaded 
videos mentioned above as the data source through YouTube by using Internet Download Manager (IDM), a software used to download a video from YouTube. Then, the writer wrote the script from the data source. Finally, the next step is grouping the data based on the sequence and context of the conversation. It means that the number of the data is based on the sequence; datum 1 is placed above datum 2 . After collecting the data, the writer analyses the data based on the research questions. The data analysis is categorized based on the answer of the research questions, which are the type and the function of codeswitching. The analysis on the function of code-switching needs a longer discussion than the discussion on the type of codeswitching because it must be explained contextually.

\section{FINDING AND DISCUSSION}

Code-switching is the use of more than one language in an utterance. Romaine (1996) stated that code-switching can be defined as the use of more than one language, variety, or style by a speaker within an utterance or discourse, or between different interlocutors or situations. The use of two languages is a phenomenon which is caused by the context and the culture makes it possible to happen. The two languages switched can be English with Indonesian. It even can be one local language with another local language. In Indonesia we see that there are some people speak Javanese with Madurese, Sundanese with Javanese and so on.

Code-switching will only occur in a conversation so it must be more than one speaker. The one who speaks alone using code-switching cannot be claimed as the phenomenon of code-switching. As what Milroy \& Musyken (2013) stated that sometimes code-switching occurs between the turns of different speakers in the conversation or sometimes between utterances within a single turn.
Code-switching occurs when the speaker speak out of the dominant language used in a conversation. When the conversant are chatting by using Indonesian, then the use of language beyond Indonesian is categorized as codeswitching phenomenon. Even if there is an English native speakers who can speak Indonesian and their way of using Indonesian in conversation which has participant from Indonesia is to show participant's solidarity. For example

$\mathrm{X}$ :Dari mana ente?

Where have you been?

Y:Alhamdulilah, ana dari Bandung. Alhamdulilah, I am from Bandung.

It shows that $\mathrm{Y}$ showed respect while saying Arabic, that is ana 'I' to replied $\mathrm{X}$ who used Arabic while saying ente 'you'.

This research uses Hoffman's theory to analyze the types of code-switching. According to Hoffman (1991), there are five types of code-switching, (1) intrasentential code-switching which happens in the middle of a sentence and usually used by fluent multilingual person; (2) intersentential code-switching which occurs between sentences; (3) emblematic or tagswitching; (4) involving a change of pronunciation, which is a shift of pronunciation when there is a word from another language changed the pronunciation into another language; and (5) establishing continuity toward previous speaker, a kind of code-switching which is a repetition of a foreign language.

This research uses Holmes theory to analyze the function of code-switching. According to Holmes (2013), there are three functions of code-switching, (1) participant's solidarity and status, (2) topic switch, (3) affective functions which is divided into five, those are increasing prestige to be viewed as an educated person, covering inability in speaking certain language, reducing or avoiding face, making amusing situations by using humour, expressing disapproval and anger. 
This section presents the findings and the discussion or analysis on types and functions of code-switching used by Sacha Stevenson in the Tonight Show and Sarah Sechan.

\section{Findings in Tonight Show on NET TV}

Tonight Show is a TV talk show hosted by Desta and Vincent, which are Indonesian, and the audiences are also from Indonesia. Therefore, the conversation in Tonight Show dominantly spoke in Indonesian. The analysis will focus on the use of English as code-switching made by Sacha Stevenson.

In this subchapter, the writer analyzes the data found in Tonight Show to answer the research questions. There are 6 data found, those are

\section{Datum I}

Datum I occurred in the first talk show interviewing Sacha Stevenson in Tonight Show. Desta tried to talk with her by using English. However, she replied the answer by using Indonesian. And then, Desta and Vincent asked about her experience in Indonesia by using Indonesian. Then, she answered that she firstly came to Indonesia in 2001 to teach English.

1. Desta : Okeh, let's continue, okeh?

2. Alright, okeh okeh, when the first time you come to Indonesia?

3 Sacha : dua ribu satu.

4 Desta : Nah kalo begitu kita pakek Indonesian Indonesia!

5 Vincent : Ndak ndak ndak, biarin biarin!

6 Desta : Yang bule pakek Indonesian Indonesia, yang lokal malah pakek Indonesian

$7 \quad$ Inggris.

8 Vincent : Iya 'kan culture shock, kita lagi bahas culture shock. Continue!

9 Desta : two thousand and one?

10 Sacha : Iyak dua ribu satu came here untuk mengajar Indonesian Inggris.
In datum 1, the conversation was started by Desta by asking Sacha "when the first time you come to Indonesia?" Then, she answered "dua ribu satu" in line 3 which was strengthened in line 10. The italic words showing that there is a switch from Indonesian to English by saying "iyak dua ribu satu came here untuk mengajar Indonesian Inggris. She switched from Indonesian by saying "iyak dua ribu satu" into English by saying "came here" and then switched it into Indonesian again by saying "untuk mengajar Indonesian Inggris". It is occurred within a sentence which is categorized as an intra-sentential code-switching. She said "came here" in the middle of the sentence. In another case, Sacha is as a bilingual person and can speak Indonesian fluently. She might have known how to say "came here" in Indonesian. However, she could not say it in Indonesian spontaneously while having conversation. Therefore, she used code-switching to cover the difficulty in speaking Indonesian.

\section{Datum 2}

In datum 2, the host strengthened the questions on the culture shock which might be experienced by her in Indonesia, especially about the foods.

1 Desta : Sekali setahun dia kembali ke Kanada. Di Jakarta mengalami

$2 \quad$ culture shock nggak? Eee traffic jam or apalah?

3 Vincent : Food? Makanan?

4 Desta : Kaki? Gua kira kaki? E

food? Food?

5 Sacha : Eeee ada sih. Well, waktu pertama kali datang, apa yah? Saya sangat 6 terbuka, just like ini negara pasti banyak perbedaan jadi saya tidak

7 terlalu nangis - nangis lihat orang makan grashopper.

8 Desta : Grashopper? Oo makan belalang? Capung?

9 Sacha : Capung mungkin?

10 Desta : Cepang?

11 Vincent : Cencoran? 
12 Sacha : siapa itu? You know look at grass sort of thing?

13 Desta $\quad$ : Belalang? digoreng. That's so weird stuff for me, I 15 don't like. Apakah saya mau mencoba? Tidak terlalu, tapi silahkan! 16 Vincent : Tapi sangat enak loh! 17 Desta : Kalo capung itu dragonfly. Saya baru inget.

In datum 2, code-switchings were written in italic word. In line 5, she said "well" which was switched into Indonesian by saying "waktu pertama kali datang ..." in a sentence which is categorized as tag switching. She used "well" while thinking what she would say next. For the function, it seems that she switched the language into English because she could not find the vocabulary in Indonesian spontaneously. She must have known that well means baik because this expression is a common expression in daily conversation. It means that not only a fluent speaker of Indonesian who can use this expression. It is impossible that she has not known how to say that expression in Indonesian. It shows that she uttered "well" to cover the difficulty in speaking Indonesian.

In line 6, she said "just like" in the middle of speaking Indonesian "Saya sangat terbuka, just like ini negara pasti..." which is categorized as intra-sentential code-switching. It looks like that she switched the code (from Indonesian to English) because she could not find the vocabulary in Indonesian spontaneously. She must have known that just like means seperti because it is a common expresson in daily conversation. Therefore, she said "just like" to cover the difficulty in speaking Indonesian. In line 7, she said grasshopper after she spoke in Indonesian by saying "... ini negara pasti banyak..." occurring in a sentence. It is categorized as intra-sentential code-swiching. It might have different function with line 5 and 6 because she switched belalang into grasshopper to cover inability in speaking Indonesian. In the next lines, she was told by Desta that grasshopper means belalang in Indonesian.

Code-switchings were also found in line 12 and 14 to 15 . In line 12, Sascha switched from Indonesian at the first sentence by saying "siapa itu?" into English in the next sentence by saying "you know look at grass sort of thing?" It shows that she codeswitched between sentences in line 12 which is categorized as intersentential code-switching. For the function, she might codeswitched to cover the difficulty in speaking Indonesian. In line 14 to 15 , she also codeswitched by saying "that's so weird stuff for me, I don't like" in English after saying "belalang yang kecil - kecil digoreng" in the previous sentence. It shows that the type of code-switching used by her is inter-sentential codeswitching because it happened between sentences. Code-switching used by her in line 14 to 15 might have the same function with line 12. She might have known what to say "that's so weird stuff for me, I don't like" in Indonesian, but she could not say it in Indonesian spontaneously. Therefore, she code switched in line 14 to 15 to cover the difficulty in speaking spontaneously in Indonesian.

Therefore, there are two types codeswitching used by Sacha Stevenson in datum 2, those are intra-sentential codeswitching and inter-sentential codeswitching. Intra-sentential code-switching found in line 5 and 6 . Inter-sentential codeswitching found in line 12 and 14 to 15 . However, line 5, 12 and 14 to 15 have the same function which is to cover the difficulty in speaking Indonesia. Another function found in line 4 which is to cover inability in speaking Indonesian.

\section{Datum 3}

In datum 3, Vincent asked about the contain of Sacha's videos talking about Indonesian culture uploaded in YouTube. Then, she answered that her videos are talking about reality. She also gave example from one of 
her videos in line 12. She added that the value of her videos is based on the viewer's opinion which can be good or bad.

1 Vincent : Lihat! Dia benerin sendiri, hehe terserah lo lah.

2 Yang menarik adalah, ketika mendengar tamunya Sacha

3 Stevenson, saya pernah ndenger nama ini tentang Youtube,

4 pokoknya berhubungan sama Youtube. Aku buka Youtube-nya

5 Sacha Stevenson dan itu banyak sekali video yang kamu buat soal

6 Indonesia

7 Sacha: Yah.

8 Vincent : Dan banyak, a lot of kritikan.

9 Sacha: Ada beberapa kritikan, seperti?

10 Vincent: Yah bagaimana orang Indonesia, bu.. bukan kritikan tapi lebih ke

11 realita, reality?

12 Sacha : iyah iyah, semuanya berdasarkan reality, semuanya yang pernah 13 saya lihat tapi tidak semuanya kritikan. Misalnya ada video yang

14 apa, misalnya saya lagi bermain, presenter saya di video bilang

15 "ehm, Indonesians really like white" and then aku anak kecil, aku

16 pakai pigtail lagi main golf pakek batang.

17 Desta : Iyah pakek batang? Pakek kayu?

18 Sacha: Itu bukan kritik.

19 Desta : Reality?

20 Sacha : Yah, itu reality tapi kadang kadang aku kritik juga yah soal buang

21 sampah.

22 Desta : Itu harus dikritik, it's a must!

23 Sacha : Yeah, but I don't know it's good or bad. Eh, penonton nilai sendiri

24 kalo nonton.

In line 12, Sacha repeated the word mentioned by Vincent reality which is categorized as establishing continuity toward previous speaker. It shows that she said reality to repeat what was said by Vincent as the previous speaker. Repeating what was said in answering a question can show our respect toward previous speaker.
Therefore, she might use the word reality to show participant's solidarity and status. Inter-sentential code-switching found in line 15 when she said from a sentence in line 13-16 "saya di video bilang, ehm, Indonesians really like white" and "then.." in the second sentence after speaking in Indonesian "presenter saya di video bilang". For the function, she might codeswitched in line 15 to cover difficulty in speaking Indonesian. In line 16, she said pig tail in the middle of a sentence spoken in Indonesian. Its type is intra-sentential code-switching. She might say it because she really did not know the meaning of pigtail is kuncir in Indonesian. Therefore, she said pigtail to cover inability in speaking Indonesian. In line 20, Sacha repeated again the word mentioned by Vincent reality which is categorized as establishing continuity toward previous speaker. Therefore, she might use reality to show participant's solidarity and status. In line 23, She said "yeah, but I don't know it's good or bad" which was switched in the next sentence by speaking in Indonesian "Eh, penonton nilai...". It is occurred between sentences which are categorized as inter-sentential code-switching. She might codeswitched in line 23 to cover difficulty in speaking in Indonesian because the sentence uttered by her must have been known by her as a fluent Indonesian speaker.

Therefore, there are three types of code-switching; those are establishing continuity toward previous speaker in line 12 and 20, intra-sentential code-switching in line 16 and inter-sentential codeswitching in line 15 and 23. There are two functions of code-switching, those are participants solidarity and status in line 12 and 20, covering inability in speaking in Indonesian in line 16 and covering difficulty in speaking in Indonesian in line 15 and 23. 


\section{Datum 4}

In datum 4, Desta asked Sacha why she really cares about Indonesia. She said that it is because she has got bored with her home in Canada which has been perfect. She felt like Indonesia needs more development. Therefore, she felt that she is needed in Indonesia.
1 Desta
: Sebetulnya apa sih yang membuatmu peduli sama Indonesia?
2 Sacha : You know what? I got really bored in Canada.
3 Desta : Bosen di Kanada?
4 Sacha : Because there is nothing to do, it's nothing to do. Masalahnya itu 5 udah bagus udah berkembang eeeh.
6 Desta
: Udah jadi?
7 Sacha : Udah jadi dan aku seperti iri sama ibu saya, yang hidup you know 8 lahir, you know jauh sebelum aku di sana masih ada banyak 9 halangan untuk wanita, but
I mean Indonesia masih banyak 10 tantangan. Oke, ini masih orang buang sampah sembarangan, di 11 sana sudah bersih.
12 Desta : Harus diperbaiki karena Indonesia karena kamu peduli jadi banyak 13 yang harus diperbaiki.

In line 4, she used English by saying "because there is nothing to do..." and then switched into Indonesian by saying "masalahnya itu...". One inter-sentential code-switching found above. She was asked by Desta about her reason of caring about Indonesia. In line 4, she told him that she was bored to live in Canada and she told the reason by saying "because there is nothing to do, it's nothing to do". She might have known how to say those words in Indonesian, but she did not do it. In this case, she might have difficulty in speaking Indonesian because she could not find it spontaneously.

Intra-sentential code-switchings were also found when she said you know which means kamu tahu and but I mean which means tetapi saya tidak tahu as in line 7 until 10 It shows that in Indonesian term, those words are commonly uttered by a fluent Indonesian speaker in a daily conversation. In this case, she also used code-switching to cover difficulty in speaking in Indonesian.

Therefore, it shows that there are two types of code-switching found in datum 4 , those are intra-sentential code-switching in line 4 and inter-sentential code-switching in line 7 until 10. The functions of all codeswitchings found in datum 4 are to cover difficulty in speaking Indonesian.

\section{Datum 5}

Datum 5 is talking the same topic with datum 4. It talked about Sacha's concern with Indonesia. Vincent asked a funny question why it must be Indonesia and not India, China and other countries. Then, she answered that she chose Indonesia because she has married Indonesian. She strengthened it in the last line of datum 5 that she chose Indonesia because she felt that Indonesia is a huge, awesome and potential country.

1 Vincent :Kenapa harus Indonesia? Kan ada India, ada China...

2 Sacha :Kan tinggal di sini.

3 Desta :Kan kawin sama orang Indonesia.

4 Desta : Ini dia kawin sama orang Indonesia.

5 Sacha : Karena saya tinggal di sini. It is a huge country, it it is a huge huge 6 potential, this place is like awesome, so awesome. sayang harus ada

7 yang diberesin sedikit tapi it is so so potential.

In line 5 until 6 , she said it is a huge country, it is a huge huge potential, this place is like awesome, so awesome. after saying karena saya tinggal di sini in the previous sentence. It shows that codeswitching occurred between sentences which called inter-sentential codeswitching. The conversation occurred while 
Sacha was asked by Vincent about her choice of living in Indonesia. Then she answered in line 6. She said it is a huge country, it it is a huge huge potential, this place is like awesome, so awesome which means that she might intend to say that the beauty of Indonesia cannot be expressed in words. She might utter that sentence to increase prestige to be viewed as an educated person because she might want to tell the participants that she has more insights about Indonesia. In line 7, intrasentential code-switching is found when she said it is so so potential after saying ... sedikit tapi in a sentence. It also has the same function with line 5 and 6 that is increase prestige to be viewed as an educated person.

Therefore, there are two types of code-switching found in datum 5, those are inter-sentential code-switching in line 5 to 6 and intra-sentential code-switching in line 7. The function of code-switchings found in datum 5 is increasing prestige to be viewed as an educated person.

\section{Datum 6}

Datum 6 talked about Sacha's videos entitled "How to Act Indonesian". Desta asked her about where she got inspirations to make up with the topic. She answered that she got inspiration after watching/observing many Indonesian people's daily activities. Then she tried to make videos which can be recorded even in the boarding house.

1 Desta : Okey, dapat dari mana inspirasi How to Act Indonesian?

2 Sacha : Okey, aku dari dulu ingin bikin Youtube series. Mau hidup di dunia

3 Youtube dunia maya gitu, and eee aku bikin abc kurang gimana and 4 terlalu banyak kerja, saya dulu terlalu banyak kerja dan untuk bikin 5 itu mungkin satu video baru jadi. Apa yang bisa saya lakukan yang
6 satu hari jadi dan bisa dilakukan di kosan saya dan tidak harus butuh

$7 \quad$ orang lain and aku mikir aku tahu banyak tentang kelakuan orang 8 Indonesia sehari-hari, aku niru aja mereka.

In line 2, code-switching occurred when Sacha uttered in English series after speaking in Indonesian by saying aku dari dulu ingin bikin Youtube in a sentence. It occurred in a sentence which is categorized as intra-sentential code-switching. It shows that she did code-switching to cover the difficulty in speaking in Indonesian because she must have known the meaning of series is serial. Then she said and in line 3 and 7. In line 3, she said and switched into Indonesian by saying eee aku bikin abc kurang gimana and switched again into English by saying and in a sentence. It means that she used code-switching in a sentence which is categorized as intrasentential code-switching. It shows that she said and to cover difficulty in speaking in Indonesian. She might clearly have known the meaning of and in Indonesian but she could not express it spontaneously. In line 7, she also said and after speaking in Indonesian by saying tidak harus butuh orang lain in a sentence. It means that it also occurred in sentence which is categorized as intra-sentential codeswitching. Code-switching in line 7 has the same function found in line 3 . It is because she could not say and spontaneously in a conversation.

Therefore, the type of codeswicthings found in datum 6 is intrasentential code-switching occurred in a sentence. The function found in datum 6 is covering difficulty in speaking in Indonesian. It shows that she could not express series and and in Indonesian spontaneously while having conversation. 


\section{Findings in Sarah Sechan on NET TV}

Sarah Sechan is a TV talk show on NET TV. The host is Sarah Sechan which is from Indonesia and the audiences are also from Indonesia. Therefore, the conversation in Sarah Sechan dominantly spoke in Indonesian. The analysis will focus on the use of English as code-switching made by Sacha Stevenson. There are 8 codeswitchings in Sarah Sechan.

\section{Datum 7}

In datum 7, Sarah intended to ask Sacha about her habit in Indonesia. Sarah wanted to ensure that Sacha has been influenced by Indonesian culture for eating rice or not.

1 Sarah : Udah makan nasi?

Kalo enggak makan nasi nanti mati.

2 Sacha : Oh my God. kan udah lama di sini, sudah tahu.

3 Sarah : : Oh iyaa yaa.

In line 2, Sacha uttered Oh my God in the first sentence and then switched into Indonesian in the next sentence by saying kan udah lama..... It is a kind of emblematic or tag switching which is an English expression. As we know that she might use code-switching because she could not say Oh my God in Indonesian because it is an English expression. Therefore, she used code-switching to cover inability in speaking Indonesian.

It shows that one code-switching found in datum 7 categorized as emblematic or tag switching. She might use code-switching to cover inability in speaking Indonesian.

\section{Datum 8}

Datum 8 talked about Sacha's videos entitled "How to Act Indonesian". Sacha made the video because she has more Indonesian friends than bule friends, friends coming from Canada. Their bule friends even said you kind alike not like us anymore. Therefore, she has more Indonesian friends which made her know more about Indonesia and then it motivated her to make videos entitled "How to Act Indonesia".

1 Sarah : So far, ada 7 episode, how to act like Indonesian yeah? Gimana

2 caranya supaya kita berperilaku seperti orang Indonesia, nah itu 3 sebetulnya lucu banget, saya terus terang kalau saya melihatnya

4 ya Chika?

5 Chika : Ehm, iya?

6 Sarah : eeeee, banyak banget yang memang bener banget gitu, itu

$7 \quad$ kebudayaan kita seperti itu. Eh Sacha, kenapa kamu bikin video 8 seperti ini? Sebetulnya maksudnya apa awalnya?

9 Sacha : Well, aku lama nongkrong sama orang Indonesia. Semua teman

10 orang Indonesia mugkin 10 tahun, eeh, teman bule cuma sedikit

11 saja,

12 Sarah : ehe

13 Sacha : Terus habis itu, aku ingin masuk lagi ke dunia bule, yang di

14 Kemang, nongkrong di Kemang apa lah yaa. Kayak nongkrong 15 sama teman bule, mereka seperti "you kind alike not like us

16 anymore like kamu kurang fit, gayanya kamu terlalu Indonesia,

17 kamu harus lebih bule".

18 Sarah : ehmm,oow, mereka bilang gitu?

19 Sacha : Iyah.

20 Sarah : kamu sudah kelamaan main sama orang Indonesia jadi gak

$21 \quad$ seperti bule lagi gitu ya?

22 Sacha : "ya, gak seperti kita lagi kamu harus lebih banyak bule" I am

23 like, "hemm kamu yang harus lebih Indonesia, Aku bikin kursus 24 yah? I am just like, I am joking yaa". Cuma buat lucuan, aku gak 25 sangka oo yang nonton orang Indonesia kebanyakan.

In line 9, code-switching occurred when Sacha said Well before speaking in Indonesian aku lama nongkrong... in a 
sentence. Then, it occurred in a sentence which is categorized as tag-switching. She said well in this line when she was asked by Sarah about her actual reason of making videos about Indonesian culture. In line 15 to 16 , Sacha codeswitched while saying you kind alike not like us anymore like then she switched it into Indonesian by saying kamu kurang and then switched it again into English by saying fit in a sentence. In these lines, she talked about her friends mocking her by saying you kind alike not like us anymore like. The code-switching occurred within a sentence, thus, it is categorized as intra-sentential code-switching. Sacha might use the same function as in line 9. She looked difficult to speak in Indonesian A fluent Indonesian speaker might have known how to say you kind alike not like us anymore like and fit in Indonesian.

In line 22, code-switching also occurred when she said I am like in line 22 which was uttered after saying "...harus lebih banyak bule in the previous sentence and when she said I am just like, I am joking yaa in line 24 after saying aku bikin kursus yah? in its previous sentence. It shows that code-switchings occurred in line 22 and 24 occurred between sentences are inter-sentential code-switching. In these lines, she talked about her friends who also mocked her. She might do code-switching because she also could not say I am like and I am just like, I am joking yaa in Indonesian spontaneously.

Therefore, code-switchings found in datum 8 are tag-switching in line 9, intrasentential code-switching in 15 to 16 and inter-sentential code-switching in line 22 to 24. The function of code-switching found in datum 8 is covering difficulty in speaking in Indonesian because she could not speak in Indonesian spontaneously in a conversation.

\section{Datum 9}

Datum 9 also talked about Sacha's videos in datum 8. Sarah wanted to investigate her reason of making videos. Then, she wanted to clarify that her videos do not mock Indonesian culture.

1 Sarah : Tapi sebetulnya itu ditujukan untuk orang - orang asing,

2 sebetulnya saya ngerti sih, maksudnya bukan maksudnya meledek 3 atau apa, tapi itu melihat banyak hal yang terjadi di Indonesia. Itu 4 misalnya kayak satu,yang kelihatan misalnya yang kita kan orang 5 Indonesia siang nyapu nyapu, malam sore nyapu - nyapu, dipel 6 semua lantai, tapi di saat bener - bener buang sampah, apakah 7 orang Indonesia buang sampah pada tempatnya, gitu yah?

8 Sacha : iyah.

9 Sarah : Gitu yah? Kalo aku sih ngeledek gitu, itu bisa jadi cerminan orang $10 \quad$ Indonesia ya?

11 Sacha : Ada sebagian hal, ya itu bukan tentang jelek atau bagus, makan

12 pakek tangan apa jeleknya.

13 Sarah : Emang gitu.

14 Sacha : Ya makan aja pakek tangan, aku juga. Tapi ya kalo buang sampah

15 sembarangan ya contoh tidak bagus. Kalo mau lihat videonya,

16 emang ada beberapa hal yang negative itu termasuk apa sorry, itu 17 tergantung kita menilainya.

In datum 9, code-switching was found only in line 16 when she said negative which was switched into Indonesian by saying itu termasuk apa and then she switched it again into English by saying sorry. Therefore, the code-switching found is intra-sentential code-switching.

The conversation in datum 9 is talking about the viewer's opinion toward her videos dealing with Indonesian culture. Some of them though that the videos are mocking Indonesian culture. However, she denied it as she said in line 14 until 17 that the meaning of the videos depends on the viewer's itself. She did code-switching in line 16 while saying negative and sorry. She used both words because she intended 
to avoid the participant's misunderstanding. She was afraid if those words were spoken in Indonesian, it will provoke complains from participants. She said "negative" because she wanted to say that there are some videos talking about bad behaviour of Indonesian people. And, she said sorry because she looked like wanting to ask apologizes to audiences who have wrong opinions toward her videos. By saying sorry, she intended to strengthen that the values of her videos based on each audience opinion. It shows that she codeswitched in this datum by saying negative and sorry. Therefore, she did code-switching in datum 9 to show reducing or avoiding face which means that using code-switching to reduce the tension and misunderstanding.

\section{Datum 10}

In datum 10, Sarah asked Sacha about her first experience in Indonesia. Sacha answered that her first experience in Indonesia was becoming an English teacher.

1 Sarah : Hahahah, tapi kamu pertama datang ke Indonesia sebagai ee guru

2 ya waktu itu mengajar?

3 Sacha : Eee iya, aku ngajar dan yaa eeeh aku enggak terlalu suka ngajar.

$4 \quad$ Yaa ngajar you know cari uang.

5 Sarah : Iyaa cari uang.

6 Sacha : Iya cari uang, cari pengalaman dan segala macam tapi emm yaa $I$

$7 \quad$ started English for 7 years maybe ya tujuh tahun, aku suka sekali 8 tinggal di sini.

In datum 10, there are two codeswitchings found in line 4 and 6 to 7 . She said Yaa ngajar you know cari uang in line 4. She said you know in the middle of a sentence spoken in Indonesian. It shows that code-switching occured while Sacha making a rethorical which is categorized as tag-switching. She said you know when she wanted to strengthen her statement that she taught in Indonesia to make money. As a fluent Indonesian speaker, she might have known how to say you know in Indonesian but she could not express it spontaneously in a conversation. It shows that she used code-switching to cover the difficulty in speaking in Indonesian. In line 6 to 7, codeswitching was also found when she said "... segala macam tapi emm" which was switched into English by saying I started English for 7 years maybe and then switched again into Indonesian by saying tujuh tahun in a sentence. It shows that code-switching occurred in sentence which is categorized as intra-sentential codeswitching. In this data, she said maybe which shows that she might forget about when she started teaching English. She might say I started English for 7 years maybe because she could not say it in Indonesian spontaneously in a conversation. It means that she used code-switching to cover the difficulty in speaking in Indonesian.

Therefore, in datum 10, the type of code-switching found in line 4 is tagswitching and line 6 to 7 is intra-sentential code-switching. And, the function found is covering the difficulty in speaking Indonesian.

\section{Datum 11}

In datum 11, Sarah asked Sacha about her reason of loving Indonesia. Sacha told Sarah that she really loved Indonesian culture in the case of Indonesian people can easily sell foods without having a permission letter. She said that people in Indonesia make money everywhere or every time.

1 Sarah : Kenapa sih kamu kok suka tinggal di Indonesia?

2 Sacha : I am like, well, I don't know. Sebenarnya di Indonesia banyak

3 yang gampang. Like kalo kita mau mau makan jam 12 malam, 
4 kita cuman pikir aja tuk.. tuk.. "Sate Sate" gitu ada. You know $5 \quad$ like kalo kita mau kemana gitu selalu ada aja ojek jam berapapun. 6 Sebenarnya hidup di Indonesia itu banyak.

In datum 11, the first codeswitching was found in line 2 when she said I am like, well, I don't know which was switched into Indonesian in the next sentence. It shows that one inter-sentential code-switching is found. In line 2 , she might do code-switching because she could not say said I am like, well, I don't know in Indonesian spontaneously in a conversation. It shows that she did code-switching to cover difficulty in speaking Indonesian.

In line 3, she said like which was switched into Indonesian by saying kalo kita makan.... in a sentence. It shows that intra-sentential code-switching was found. In this case, she said like while she was thinking what to say in the next sentence. She did code-switching by saying like because she might not be able to say like in Indonesian spontaneously in a conversationIt shows that she used codeswitching to cover difficulty in speaking Indonesian.

In line 5, she said you know like which was switched into Indonesian by saying kalo kita mau.... in a sentence in line 5. It shows that tag-switching as same as in line 4 of datum 10 found. She might use code switching because she could not say You know like in Indonesian. As a fluent Indonesian speaker, she might have known how to say You know like in Indonesian which is commonly uttered by Indonesian people. It shows that she also did codeswitching to cover difficulty in speaking Indonesian.

Therefore, inter-sentential codeswitching found in line 2 and intrasentential code-switchings found in line 3 and tag-switching found in line 5. The function of code-switching found in those lines in datum 11 is covering difficulty in speaking Indonesian.

\section{Datum 12}

In datum 12, Sacha told her admiration of Indonesia. She said that in her hometown in Canada, there is no people passing her house by selling some food like in Indonesia and cannot find ojek payung, an umbrellaman used to protect consument from rain. She even said that her house in Canada is like empty, and not as crowded as in Indonesia.

1 Sarah : Di luar negeri gak ada dong ojek payung, harus bawa payung

2 sampai payung ketiup - tiup ke atas - atas. Di Indonesia aman kan?

3 Mau makan? Ada yang lewat depan rumah. Di Kanada, ada orang $4 \quad$ sate lewat depan rumah?

5 Chika : Ada?

6 Sacha : Tidak ada tidak ada. Di rumahku gak ada orangpun. I mean it's like 7 like...

8 Chika : Kok gak ada sih?

9 Sarah : Kok?

10 Sacha : Maksudnya sepi.

11 Sarah : Iya di sini rame.

12 Sacha : iyah lonely di sana.

In line 6, she said I mean it's like empty, it's like which was switched into Indonesian by saying sepi and switched again into English by saying it's like. It shows that intra-sentential code-switching was found. She repeated it's like to strengthen that she is really lonely because of quite neighbours. She might have known I mean it's like empty, it's like and like in Indonesian but she could not speak in Indonesian spontaneously. It shows that she used code-switching to cover difficulty in speaking Indonesian.

In line 12 , she said lonely occurred in the middle of a sentence spoken in Indonesian. It shows that intra-sentential code-switching was found. She might have known that the meaning of lonely is 
kesepian. However, she looked like not able to say it in Indonesian spontaneously in a conversation. It shows that she used codeswitching to cover difficulty in speaking Indonesian.

Therefore, two intra-sentential codeswitchings found in line 6 and 12. Function of code-switching found in the data is covering difficulty in speaking Indonesian.

\section{Datum 13}

In datum 13, Sarah asked Sacha if there were some Indonesian people asked her to take some pictures with her when meeting her. Sacha answered that some Indonesian people asked to take a picture with her some years ago but it is not to many for today. Sarah told her that her friend had ever experienced it.

1 Sarah : gapapa, duduk situ aja. Jadi
ada e ada salah satu di video kamu itu
$2 \quad$ dari pengalaman pribadi
bukan sih? Jadi ada orang kalo misalnya
$3 \quad$ ketemu bule selalu minta
foto minta foto? Orang kalo ketemu kamu
$4 \quad$ suka minta foto minta foto
gitu nggak?

5 Sacha : emm enggak terlalu banyak, udah enggak terlalu banyak sih.

6 Sarah : Dulu iya?

7 Sacha : Waktu masih muda maksudnya. No, tapi aku pernah punya teman,

8 datang ke sini, dia gak bisa

Indonesian Indonesia, jadi cuman ya

9 datang ajah. Terus jalan

kaki gitu, I don't know ada apa gitu ada

10 orang lagi outbound or whatever, ratusan anak anak sekolah gitu

11 terus mereka pada minta foto gitu ya sekitar 200 foto dimintak.

Sacha codeswitched in the last turn of this conversation. She said no in line 7 after speaking Indonesian. It shows that intersentential code-switching found. She might use code-switching because she spontaneously say no. It shows that she also used code-switching to cover difficulty in speaking Indonesian.

The another code-switchings are when she said I don't know in line 9 which was switched into Indonesian by saying $a d a$ apa gitu ada orang lagi and switched again into English outbound or whatever in line 10. It means that those code-switchings occurred within sentences which are called as intra-sentential code-switching. In line 9 and outbound or whatever in line 10 at the last turn of the conversation. As a fluent Indonesian speaker, she must have known the meaning of I don't know is saya tidak tahu. It shows that she used code-switching to cover the difficulty in speaking in Indonesian. She used code-switching because she could not say those words in Indonesian spontaneously in a conversation whereas the meaning of those words in Indonesian are commonly uttered by a fluent Indonesian speaker like Sacha. However, it is different case when she said outbound or whatever. She said outbound because it is an English expression. Therefore, she said outbound to cover inability in speaking in Indonesian. And, for or whatever is to cover the difficulty in speaking Indonesian because she must have known that it means atau apa pun in Indonesian as a fluent Indonesian speaker. Therefore, inter-sentential code-switching found in line 7 and intra-sentential codeswitching in line 9 and 10. The function of code-switching, covering difficulty in speaking Indonesian found in line 7, 9 and 10. Another function of code-switching, is covering inability in speaking Indonesian found in line 9 when she said outbound.

\section{Datum 14}

In datum 14, Sarah made a joke by asking Sacha to wear the shirt from her in Sacha's next videos. Sacha even also replied that she would wear it and imitate Sarah's style.

1 Sarah : How to act Indonesian. Okeh aku kasih kamu kaos Sacha terima 2 kasih. Eh, nanti kalo kamu syuting pakai kaos aku dong? 
3 Sacha : You know? Aku nantik bikin episode buat niru kamu yah?

Sacha did code-switching in line 3 when she said "You know" which was switched into indonesian in the next sentence by saying "Aku nantik bikin episode...". It is categorized as tagswitching. In this conversation, Sarah asked Sacha to wear her shirt in her next videos. And, Sacha answered that she will do it later and imitate Sarah's style. Sacha used code-switching while saying you know in line 3. She said you know when she wanted to make the listeners guess what she would say. It also shows that she used codeswitching to cover the difficulty in speaking in Indonesian. It is because the meaning of you know in Indonesian is kamu tahu is commonly uttered by a fluent Indonesian speaker like her in a daily conversation.

\section{CONCLUSION}

Sarah Sechan and Tonight Show are two popular TV talk shows. Both have hosts and audiences from Indonesia. It makes Sacha used Indonesian as a dominantly used language because she wanted to respect the others or to show partcipant's solidarity and status. However, Sacha could not stop using her native language within the conversation. Therefore, she did codeswitching within the conversation.

Based on the findings and discussion, the types of code-switching found in both data sources are inter-sentential codeswitching and intra-sentential codeswitching, establishing continuity toward previous speaker was also found and emblematic or tag-switching.

Meanwhile, the function of codeswitching, covering inability in speaking Indonesian spontaneously, covering the difficulty in speaking Indonesian and reducing or avoiding face and increasing prestige to be viewed as an educated person in the Tonight Show and Sarah Sechan. However, covering inability in speaking in Indonesian and participant's solidarity and status were also only found in the Tonight Show.

For future research, the next researcher can do an empirical comparative study of using code-switching between native English speaker and native Indonesian speaker in using English and Bahasa Indonesia.

\section{DAFTAR PUSTAKA}

Creswell, J. W. (1994). Research Design Qualitative and Quantitative Approaches. London: Sage Publications.

Hoffman, C. (1991). An Introduction to Bilingualism. London: Longman.

Holmes, J. (2013). An Introduction to Sociolinguistics (Fourth Edit). London and New York: Routledge, Taylor and Francis Group.

Ibrahim, E. H. E., Shah, M. I. A., \& Armia, N. T. (2013). Code-Switching in English as a Foreign Language Classroom: Teachers' Attitudes. English Language Teaching, 6(7), 139-150.

Kumalasari, R. V. (2008). A study of Code switching in "Empat Mata" Talk Show (Skripsi). Unversitas Katolik Soegijapranata, Semarang.

Milroy, L., \& Musyken, P. (Eds.). (2013). One Speaker, Two Languages: CrossDisciplinary Perspectives on CodeSwitching (10th Edition). Cambridge: Cambridge University Press.

Romaine, S. (1996). Bilingualism. Oxford: Blackwell Publishing Ltd. 